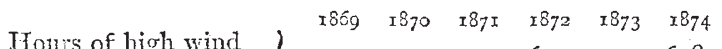

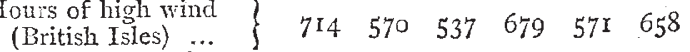

$\begin{array}{lllllll}\text { Cyclones (W. Indies) } & 0 & 7 & 3 & 0 & \text { I }\end{array}$

The period covered by the table is too short to afford any ground for a definite induction; but, as far as they go, these figures afford prima facie evidence in favour of the theory.

I may add that the probability of this relation between the gales of the temperate zones and the cyclones of the tropics has been pointed out on purely speculative grounds by Mr. E. D. Archibald, in a pamphlet on the rainfall of the world, recently published by him in India.

Allahabad, September in

S. A. HILL

\section{Magnetic Storm, May 14, 1878}

IN the Bulletin Mensuel of the observatory of Zi-ka-wei, near Chang-hai, China, the following interesting remark occurs in the number for May, 1878 :-

"Durant le mois de Mai, une seule perturbation a été enregistrée par le magnétophotographe; elle commença le 14, à $2 \mathrm{~h}$. 20m. de l'après-midi, et se termina 24 heures après; ce jour-là la déclinaison, par extraordinaire, ne présenta pas d'oscillation diurne normale, mais de très-nombreuses petites oscillations comme le bifilaire."

On examining the photographic trace of the Stonyhurst inagnetograph I find that the only magnetic storm in May last coinmenced on the 14 th at $6 \mathrm{~h}$. $4 \mathrm{~m}$., and lasted rather more than twenty-four hours. The longitude of $\mathrm{Zi}$-ka-wei being $8 \mathrm{~h} .15 \mathrm{~m} .38 \mathrm{~s}$. E. of Stonyhurst, the storm began at the same time at both stations. The character of the movement was also adentical, for the only disturbance at Stonyhurst from 6 A.M. intil 4 P.M. was a tremulons motion of the cleclination and horizontal force magnets.

The storm was at its height at midnight, when all the magnets were much disturbed, and the vertical force magnet was thrown completely off its balance.

It is impossible to obtain more than the roughest outline of a magnetic storm from hourly readings, but even this slight datum from China shows a general agreement in the declination curves cluring the storm at these two distant stations.

The Monthly Record of the Melbourne Observatory also mentions the same magnetic disturbance, which commenced there at 4 P.M. on the I4th, and lasted until 8 A.M. on the I7th. Melbourne lies 9 h. $39 \mathrm{~m} .54^{\circ} \mathrm{Ss}$. E of Greenwich, and therefore Xh. $34 \mathrm{~m}$. I03, E. of $\mathrm{Zi}-\mathrm{ka}$-wei. We thus see that the Zi-ka-wei storm commenced at $3 \mathrm{~h}$. $54 \mathrm{~m}$. Melbourne time : it was therefore simultaneous at the three observatories.

Stonyhurst Observatory, September $27 \quad$ S. J. PERRY

Winds and Currents in the Pacific

THE occasional prevalence of westerly winds and of currents setting east in the intertropical portion of the Pacific, has such an important bearing on the possible eastward migrations of the Polynesians that I think the following, which I take from the Samoa Times for A pril 2o, is worth recording in NATURE.

The brigantine Ryno is reported as having arrived at Apia, Samoa, on April 16, from the Tolkelau, or Union Group. She was among those islands from March I to April II, and, while there, she "experienced a succession of strong westerly and north-west winds, with high sea and frequent squalls and much rain, which made sad havoc amongst the vessel's canva'. Capt. Bower states that, when off Tokelau, he found a strong current setting to the eastward at the rate of two miles per hour. The Ryno left Tokelau on April II, had fine E.S.E. weather, and no current whatever."

Blackheath, September 27

\section{Blackburn's Double Penduluin}

I TRUST I may be pardoned for observing, in reference to Prof. A. M. Mayer's description of the curves produced by Blackburn's Double Pendulum (NATURe, vol. xviii. p. 594); that a typical series of those curves was placed before the readers of NATURE in the year r87i (vol. iv. pp. 310, 370), in illustration of a paper of mine on "Pendulum Autographs."

Prof. Mayer adheres to the funnel and sand as the mode of laying the curve on paper. The sand-trail thus left is necessarily rather coarse, and cannot be conveniently preserved. A more delicate and more enduring trace, in ink, can be obtained by the use of a tubular glass pen, as described by me in the paper above-mentioned. Only the increased friction makes it necessary to use a heavier bob.

HUBERT AIRY

\section{Circulating Decimal Fractions}

As a supplement to the interesting properties of circulating decimal fractions which have been published in two recent numbers of NATURE, I give you the following, which I think is sufficiently curious to merit attention :-

If the decinal fraction equal to $\mathbf{I} \div n$ recur in a cycle of $n-\mathbf{I}$ digits, the average value of the digits is constant, viz., $4 \frac{1}{2}$ for all values of $n$; in other words, the sum of the digits of the cycle is $4 \frac{1}{2}(n-1)$.

For example,--

$$
\begin{aligned}
& \begin{array}{l}
\text { and } \quad(x+4+2+8+5+7) \div 6=27 \div 6=4 \frac{1}{7}=\cdot 4285 \% \\
\text { Again, }
\end{array}
\end{aligned}
$$

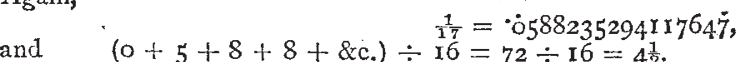

The theorem is easily established from the two facts ( $x$ ) that $1 \div n, 2 \div n, 3 \div n, \ldots$ have the same digits in their cycles, and (2) that the sum of $1,2,3, \ldots, n-1$ is $\frac{1}{2} n(n-1)$.

The properties of circulating decimal fractions have been often studied from the time of Wallis downwards, and very probably those lately and now brought forward have been noted before, but have lain entombed in some out-of-the-way corner since. However, until a full index to mathematical literature is prepared, or exhaustive monographs on special departments like this are written, such resurrections are very desirable.

If either of your two previots correspondents on the subject would care to undertake a full examination of it $I$ should be glad to furnish him with my quota of references to the extent of ten or a dozen, and, I have little doubt, other readers of NATURE would give like help.

High School of Glasgow, September 23

[Mr. Muir's theorem is practically contained in the result that the two halves of the period are complementary, whence the sum of the figures is equal to half as many nines as there are figures in the period.-ED.]

\section{An Old Map of Africa}

EARLY in the year $1870 \mathrm{I}$ visited the vineyard of $\mathrm{Mr}$. J. L. Cloete at Constantia, near Cape Town.

Among other things of interest $\mathrm{M}$. Cloete showed me an old map of Africa done, I think, in Amsterdam. This map had been in the possession of his family from time immemorial. My acquaintance with the geography of Africa was too slight to enable me to pronounce upon its accuracy, but I was greatly surprised to see marked upon it several large lakes and many rivers in the region now so well known to us through recent explorations.

In the critical study of this subject I have thought that a knowledge of the existence of this map, if it be as I remember it, might prove of value.

Torpedo Station,

Newport, Rhode Island C. F. GOODRICH,

Lieut.-Commander, U.S. Navy

[We wrould refer Commander Goodrich to our article on Old Maps of Africa, in NATURE, vol. xviii. p. I49.-ED.]

\section{Earth Pillars}

A LeTter in your issue for September 26 (p. 569) refers to miniature earth pillars seen in the Tyrol. But there is no need to travel out of the country to obtain these mimic representations, at any rate on a moderate scale. Twice I have found them, formed by the drops from railway bridges, upon bare clays; and once in a half-finished building, in a sand-heap containing numerous pebbles. Evidently the heavy drops and the protection from driving rain favoured the result. One of the bridges, between Shepton Mallett and Wells, Som., covered Lias clays, protected by cinders, \&c. The other instance, the bridge on the new North Approach just outside York Station, is the more interesting in its mimicry of the original Botzen earth pillars, since small boulders and pebbles in the glacial clays form the caps and shoulders in the Lilliputian columns.

September 28
J. Edmuind Clark 